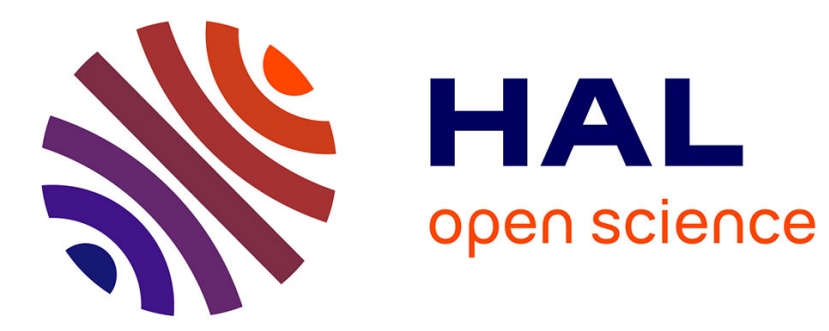

\title{
Arcing on Solar Generators by Collection of Ionospheric Plasma Currents
}

Virginie Inguimbert, Jean-Michel Siguier, Gaël Murat

\section{To cite this version:}

Virginie Inguimbert, Jean-Michel Siguier, Gaël Murat. Arcing on Solar Generators by Collection of Ionospheric Plasma Currents. IEEE Transactions on Plasma Science, 2019, 47 (8), pp.3877-3884. 10.1109/TPS.2019.2916594 . hal-02456014

\section{HAL Id: hal-02456014 https://hal.science/hal-02456014}

Submitted on 27 Jan 2020

HAL is a multi-disciplinary open access archive for the deposit and dissemination of scientific research documents, whether they are published or not. The documents may come from teaching and research institutions in France or abroad, or from public or private research centers.
L'archive ouverte pluridisciplinaire HAL, est destinée au dépôt et à la diffusion de documents scientifiques de niveau recherche, publiés ou non, émanant des établissements d'enseignement et de recherche français ou étrangers, des laboratoires publics ou privés. 


\title{
Arcing on solar generators by collection of ionospheric plasma currents
}

\author{
Virginie Inguimbert, Jean-Michel Siguier and Gaël Murat
}

\begin{abstract}
There are several well-known possibilities to trigger a secondary arc on solar arrays by creation of conductive plasma produced in the gap between two solar cell strings. It could be by electrostatic discharges due to an inverse potential gradient condition, micrometeoroid impacts or laser impacts. The development of electrical propulsion for satellites requires higher voltages on solar arrays. These voltages strongly modify the plasma-satellite interactions, especially by increasing the collection of plasma currents. By studying this plasma collection current on solar cell samples, we have detected secondary arcs between two strings without any triggering event as previously described. Focusing on this event, we found that a series of physical phenomena may lead to secondary arcing situation: heating by plasma current collection, outgassing, Paschen discharge conditions and then secondary arcing. We have reproduced on solar cell like samples what occurs when an arc starts and the conditions for its occurrence. Thereby, we have defined when this phenomenon is able to happen on real solar arrays.
\end{abstract}

Index Terms-satellite, solar cell, solar panel, electrostatic discharge, electrical arcing

\section{INTRODUCTION}

$\mathbf{I}_{s}^{N}$ MPLEMENTATION of electrical propulsion on new generation satellites lead satellite manufacturers to develop solutions to increase voltages on solar arrays [1]. These higher voltages have different consequences on the spacecraft electrostatics [2] and require solar panel testing [3] [4]. In particular, they increase the collection of plasma currents [5], which are also greatly enhanced when the plasma thrusters are running.

A preliminary work, funded by an R\&T CNES program, was carried out in 2015 in order to study if secondary arcs could be triggered between two solar cell strings with high Vbus voltage when the surrounding plasma is enhanced, up to $10^{13} \mathrm{~m}^{-3}$, by electric propulsion even without the ignition by a primary arc. Surprisingly, secondary arcs were triggered even for low plasma density $\left(10^{11} \mathrm{~m}^{-3}\right)$ that are typical ionospheric values and medium range Vbus values $(250 \mathrm{~V})$.

Because the solar cells coupon was floating in the plasma,

This work was part of "HV-EPSA" (High Voltage Electrical \& Power System Architecture) R\&D project supported by "Horizon 2020" European research and innovation framework program.

Jean-Michel Siguier is with ONERA/DPHY, Université de Toulouse, France (e-mail: jean-michel.siguier@ onera.fr).

Virginie Inguimbert (Virginie.inguimbert@onera.fr) and Gaël Murat (Gael.murat@onera.fr) are also with ONERA/DPHY, Université de Toulouse, France we supposed that the most negatively biased solar cell was in an inverse potential gradient (IPG) situation. This IPG is generally observed on the front face of solar arrays when the spacecraft is negatively charged due to charging events such as geomagnetic storms and the coverglasses are less charged due to both photoemission and secondary electron emission. This condition triggers electrostatic discharges leading possibly to secondary arcs [6], [7], [8].

Then, to suppress the IPG situation, the negatively biased solar cell was grounded. Thus, the positively biased solar cell was at +Vbus voltage versus plasma floating voltage (Vf), considering that $\mathrm{Vf}$ is few volts below zero. In this configuration, secondary arcs were also triggered.

Therefore, we made assumptions for secondary arc origin based on similar behaviors observed in a study carried out in our lab for a European research program (BET's) in 2012 [9] :

- Positively biased solar cell collects, on the cell edge, plasma electrons accelerated by Vbus. These electrons have a kinetic energy of about $0.25 \mathrm{~W}$ (=V.I).

- This energy is absorbed by the rear side metallization of the solar cell. Because this metallization is very thin (few microns), it induces an increase of the temperature, which induces outgassing of the coverglass glue.

- Outgassing increases locally the pressure in order to be in Paschen discharge conditions and this Paschen discharge triggers the secondary arc.

The study presented in this paper was performed in the frame of HV-EPSA Project (funded by the "Horizon 2020" European research and innovation framework program) and aims to demonstrate that :

- The secondary arc triggering occurs on other solar cell types if there is coverglass glue.

- The secondary arc may occur on any kind of structure where plasma electron current is collected by a metallic strip and heat a material able to outgas.

- If there is no glue (outgassing material) close to the collecting metallic strip, there is no arc.

\section{SETUP}

Tests were performed in the JONAS facility (Fig. 1) located at ONERA/DPHY-Toulouse. It is basically a $10 \mathrm{~m}^{3}$ cylinder hemispherical vacuum chamber. It is equipped with a plasma source, two $10 \mathrm{keV}$ electron guns and several electrostatic discharges (ESD) and plasma diagnostic devices such as transient current probes, surface potential probes, Langmuir probes, etc. [10]. 
A cryogenic pump provides a working pressure better than $10^{-9} \mathrm{~Pa}$. The working pressure with plasma is about $5 \times 10^{-8} \mathrm{~Pa}$.

Earth magnetic field is totally compensated by external coils within a volume of about $2 \mathrm{~m}^{3}$ in the center of the chamber. The compensation decreases getting closer to the chamber walls.

The plasma source is a Kauffman type, providing 10 to $30 \mathrm{eV}$ drifting Ar+ ions set accurately by the anode power supply. The energy range corresponds to the orbital velocity $(8 \mathrm{~km} / \mathrm{s}$ for $20 \mathrm{~V})$. This plasma consists of two ions populations: drifting ions and low energy ions (after interaction with neutrals). Rough characteristics are: $\mathrm{Ni}=10^{11}$ to $10^{13} \mathrm{~m}^{-3}, \mathrm{Te} \approx 0.1 \mathrm{eV}$ to $0.2 \mathrm{eV}$. Argon is used as an inert gas, the most similar to oxygen (LEO plasma constituent). Plasma distribution inside JONAS chamber is shown in Fig. 2. This plasma distribution is modelled by the ONERA code: SPIS (Spacecraft Plasma Interaction Software) and confirmed by Langmuir probe measurements [11].

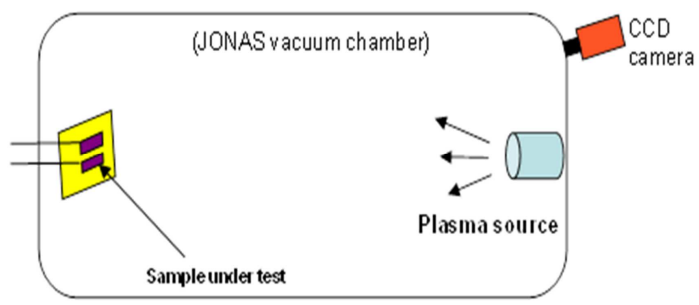

Fig. 1. Schematics of JONAS facility

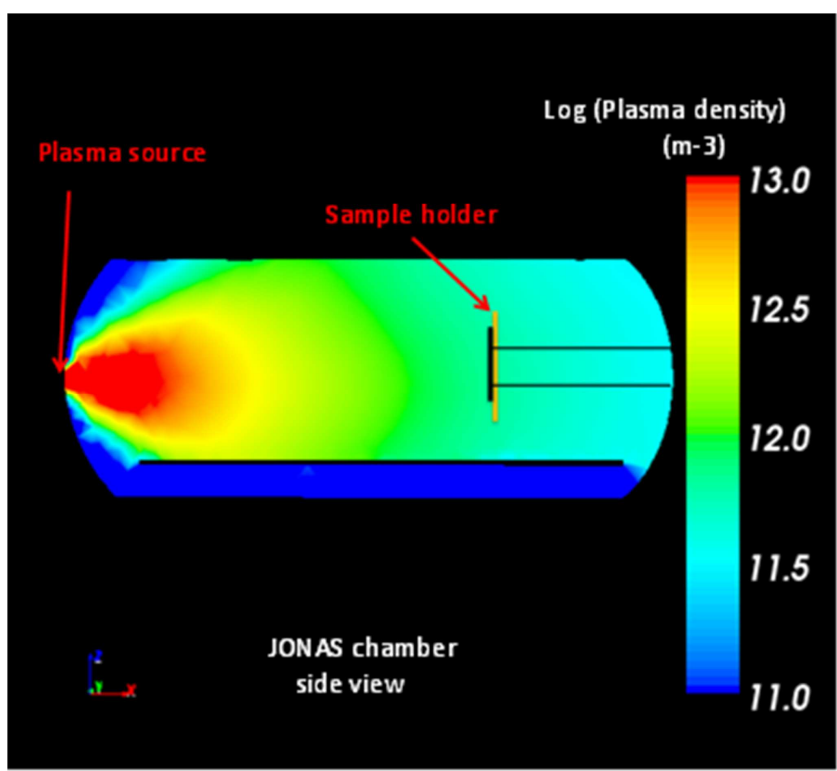

Fig. 2. Plasma distribution inside the JONAS chamber

The samples were placed on a sample-holder (Fig. 3) set at $1.8 \mathrm{~m}$ from the plasma source. The description of the test samples is given in the followings.

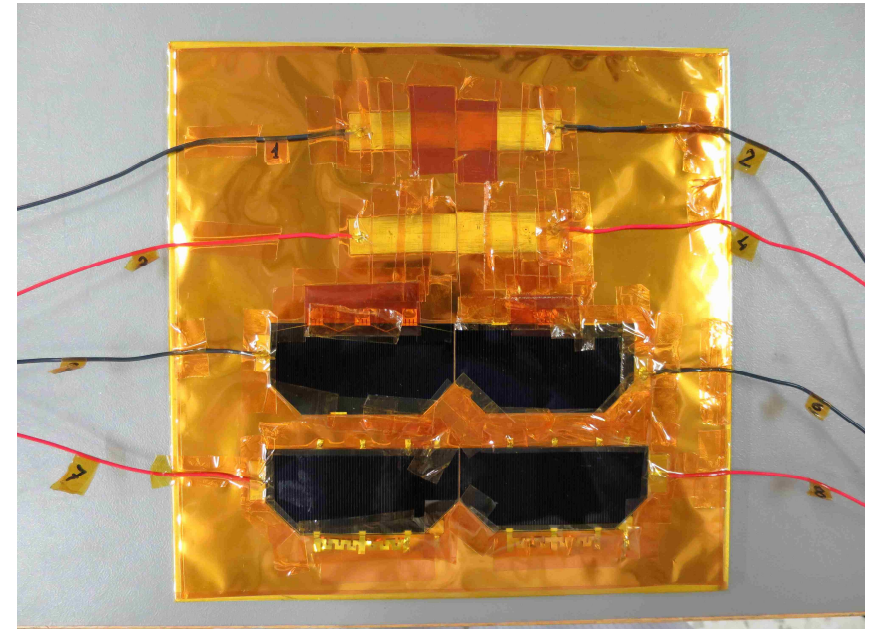

Fig. 3. Example of a sample holder with 4 samples which can be tested successively without opening the chamber

The electrical setup is shown in Fig. 4.

The SAS (solar array simulator) consists of a power supply $\mathrm{V}_{\mathrm{A}}$ and a current limiter. It limits the current to a fixed value (= 3A) without overshoot current when an arc occurs. In order to avoid damaging the sample under test, the arc current is also limited in duration to a few ms. This limitation is insured by inserting a capacitance in the circuit. When an arc occurs, the charge delivered by this capacitance is finite and corresponds only to the stored charge. The value of the couple (capacitance; resistance) is determined by the best compromise between arc duration and time to re-charge the capacitance. Due to the addition of this limitation system, the circuit cannot be closed and there is no current flowing into the cells before an arc occurs.

Once the plasma is set (between $10^{10} \mathrm{~m}^{-3}$ and $10^{13} \mathrm{~m}^{-3}$ ), Va voltage is increased, with $50 \mathrm{~V}$ steps up to $500 \mathrm{~V}$ or until an arc occurs.

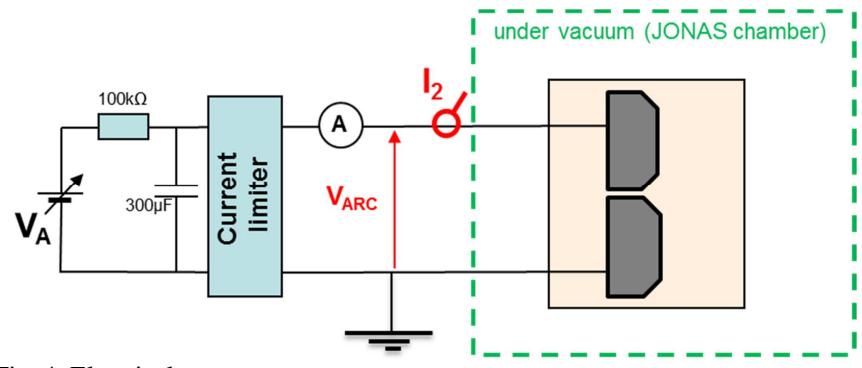

Fig. 4. Electrical setup

A short-circuit is performed before each step between the two samples wires, with a $6 \Omega$ resistor, in order to check that all parameters are well adjusted.

Fig. 5 is an example of current and voltage measurement for SAS values: $100 \mathrm{~V}-3 \mathrm{~A}$ and plasma off. We can see on this graph that the current is maintained constant by the SAS until there is not enough charges inside the capacitance and the signal becomes to decrease. With a current limited to $3 \mathrm{~A}$, the maximum duration for the arc is about $6 \mathrm{~ms}$. 


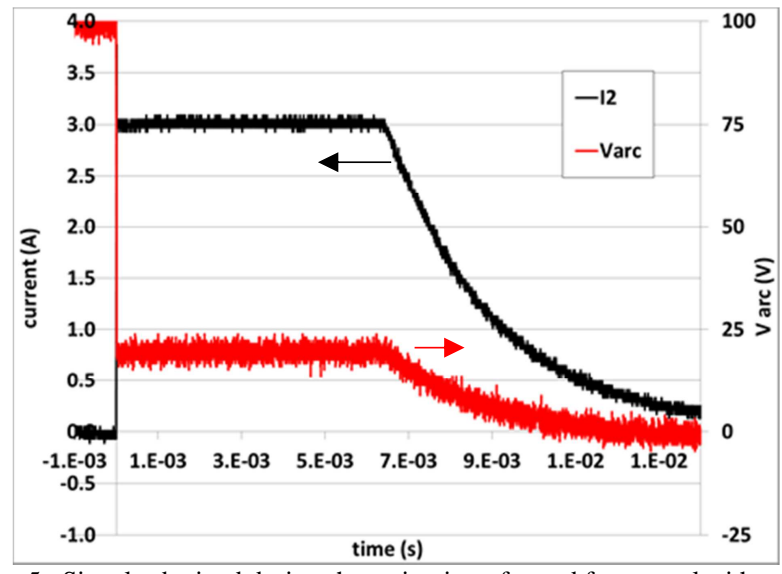

Fig. 5 : Signals obtained during short-circuit performed for control with a resistor of $6 \Omega$

\section{ARCING TESTS ON SOLAR CELL SAMPLES}

\section{A. Solar cell - Config \#1}

1) Sample description

The aim of thefirst step of this study was to reproduce previous results, described in section. I: arcing between 2 solar cells. The first arcing test was performed with 2 solar cell assemblies (SCA) that is a solar cell + glue + coverglass + interconnectors. Solar cells were 3G28 type from Azur Space. The sum of the thicknesses of all elements (cell : $140 \mu \mathrm{m}$, coverglass : $100 \mu \mathrm{m}$ and glue : a few tens of $\mu \mathrm{m}$ ) was about 300 $\mu \mathrm{m}$. The glue was a classical silicon-based glue.

Both cells were separated with a gap of $0.5 \mathrm{~mm}$ (Fig. 6). All the metallic parts were protected with Kapton ${ }^{\circledR}$ tape in order to collect plasma current only by the cell edges facing each other (intercell's gap).

Details of cell structure are shown in Fig. 7.

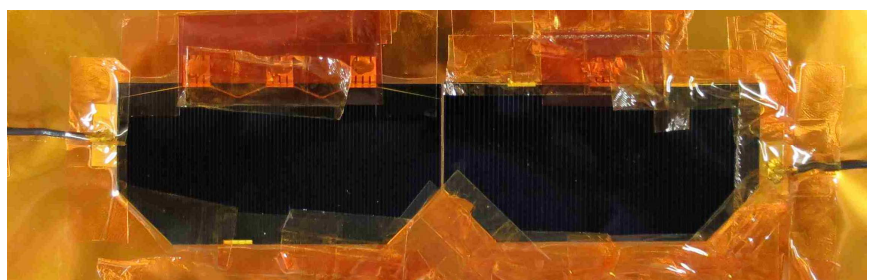

Fig. 6. Solar cell sample. Configuration \#1

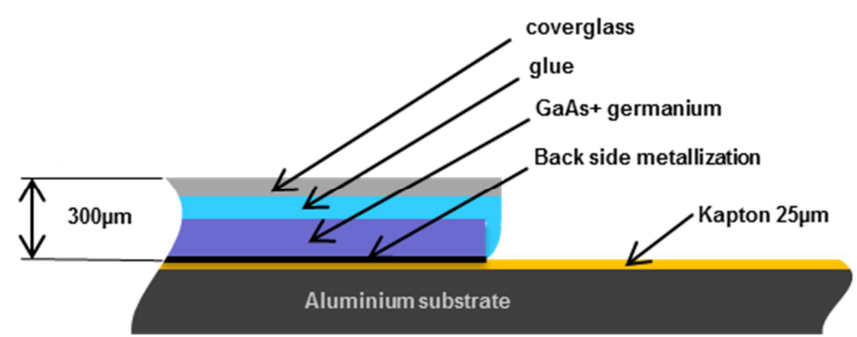

Fig. 7. Detail of cell edge. Cell configuration \#1

\section{2) Arcing test results}

Plasma density at the sample location was set to $7.10^{11} \mathrm{~m}^{-3}$.
SAS current value was $3 \mathrm{~A}$ and SAS voltage was applied with $50 \mathrm{~V}$ increments waiting about 1 minute at each step, duration estimated to be long enough to initiate an arc if the conditions are met. Hence, the previously presented arcs were observed only a few seconds after the voltage was applied.

The first arc occurred at $250 \mathrm{~V}-3 \mathrm{~A}$. It stopped after $6 \mathrm{~ms}$ and arc voltage was about $30 \mathrm{~V}$ (see signals on Fig. 8).

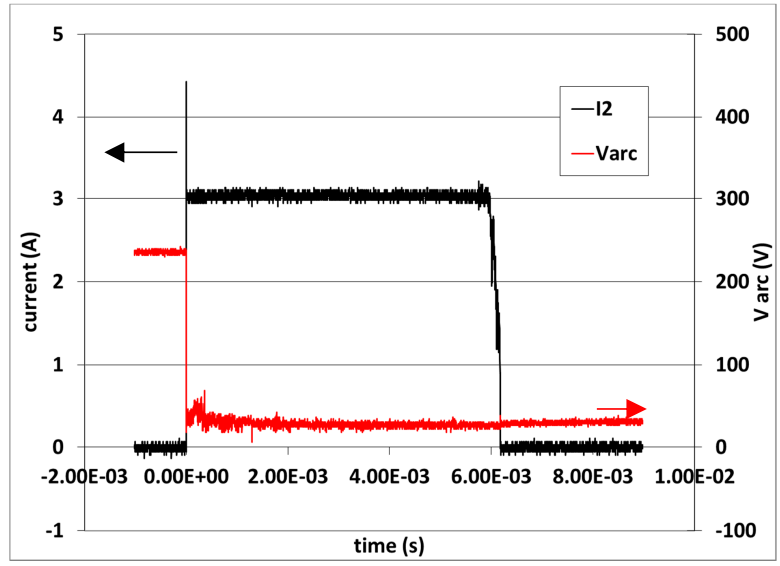

Fig. 8. Arc characteristics on solar cell sample \#1

We can observe a few differences between this arc signals and those of the short-circuit shown in Fig. 5. Hence, on this result, the arc current stops more rapidly and arc voltage stays low even when arc has stopped. In the first case, the short-circuit remains after the first $7 \mathrm{~ms}$ because it is performed manually and lasts about $1 \mathrm{~s}$. The current and consequently the voltage are limited by the fact that the capacitance is emptying. In the second case, as soon as the arc current begins to decrease, the arc stops certainly because the current is not sufficient to maintain the arc. Then, the power supply starts to charge again the capacitance but this phenomenon takes about 30s and is not visible with the timebase of the oscilloscope.

The same test was repeated with a lower plasma density set to $5.10^{10} \mathrm{~m}^{-3}$ and the same result was obtained, that is: an arc for 250V-3A SAS values and same arc characteristics ( $\operatorname{Varc}=30 \mathrm{~V})$. Enhanced photographs taken on the cells edges showed that an anodic spot was created at the backside metallization on the edge of the positively biased cell. Fig. 9 shows the heated area of the metallization and Fig. 10 shows the deposit on the cell edge (covered with glue) of the evaporated metallization, both photographs were taken on the positively biased solar cells.

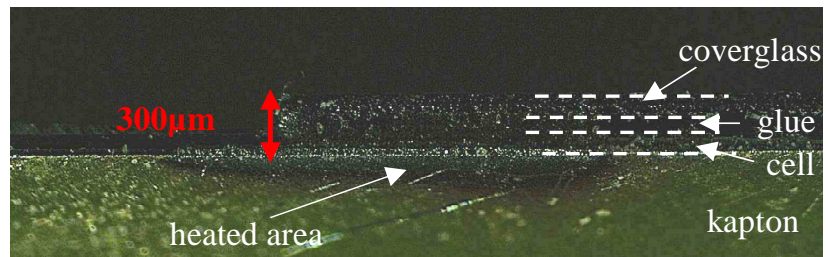

Fig. 9 : Heated area of the back side metallization of the cell 


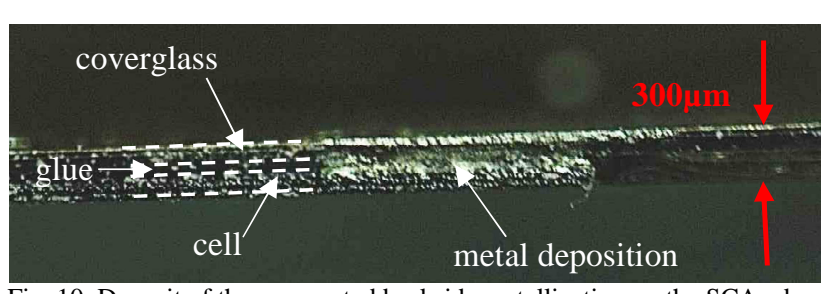

Fig. 10. Deposit of the evaporated backside metallization on the SCA edge

\section{B. Solar cell - Config \#2}

\section{1) Sample description}

Once the previous results confirmed, the idea was to verify that the arc was due to the presence of glue onto the solar cell. A new sample was prepared with a $2 \times 2 \mathrm{~cm}^{2}$ solar cell without coverglass or glue (Fig. 11 and Fig. 12). The cell was covered with only a $125 \mu \mathrm{m}$ Kapton film (no glue) to simulate the coverglass and thus to prevent the solar cell from collecting plasma current by the front side as it is in reality. The cells were spaced with $0.6 \mathrm{~mm}$ gap (same as configuration \#1).

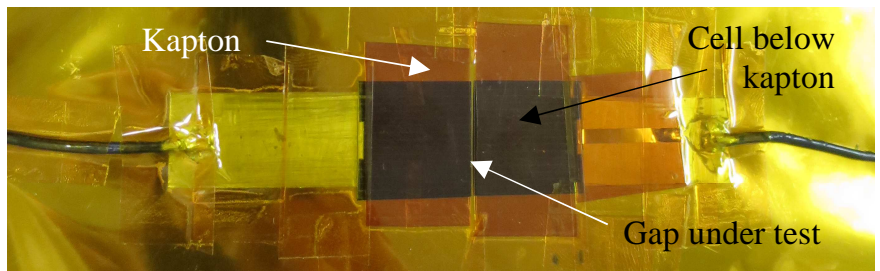

Fig. 11. Cell configuration \#2

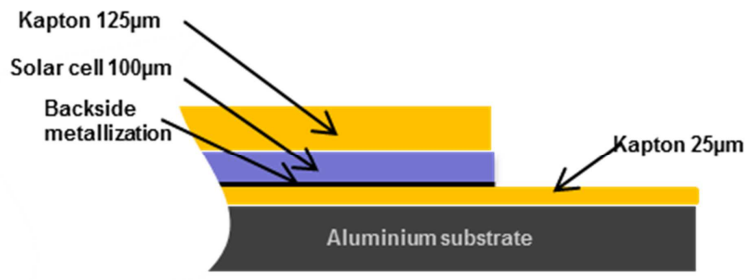

Fig. 12. Detail of cell edge. Cell configuration \#2

\section{2) Arcing test results}

In this configuration, no arc was detected up to SAS values of $450 \mathrm{~V}-3 \mathrm{~A}$ (maximum tested voltage), in agreement with the assumption that the presence of glue was important in the arcing process.

\section{Solar cell - Config \#3}

\section{1) Sample description}

To get closer to configuration \#1, the $2 \times 2 \mathrm{~cm}^{2}$ solar cell was then covered with adhesive transfer tape $3 \mathrm{M} \otimes$ (ref. 3M 467 MP) which simulated the coverglass glue and was supposed to outgas similarly as silicon base coverglass glue. A $125 \mu \mathrm{m}$ Kapton film covered the adhesive transfer tape to simulate the cover glass (Fig. 13 and Fig. 14). Here the intercell gap was $0.8 \mathrm{~mm}$.

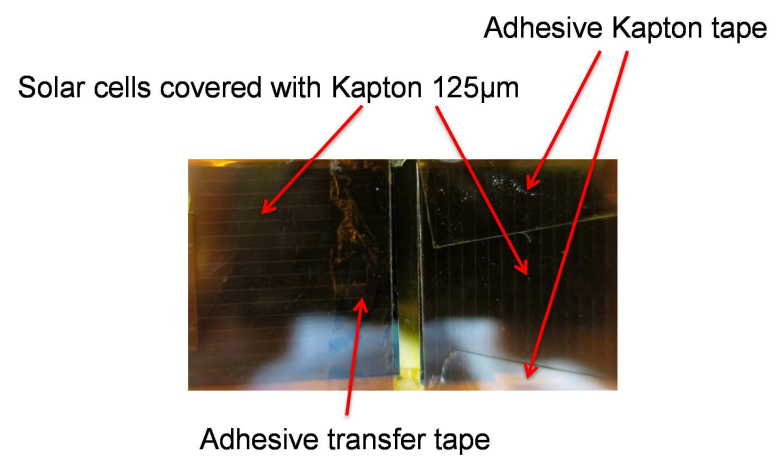

Fig. 13. Cell configuration \#3

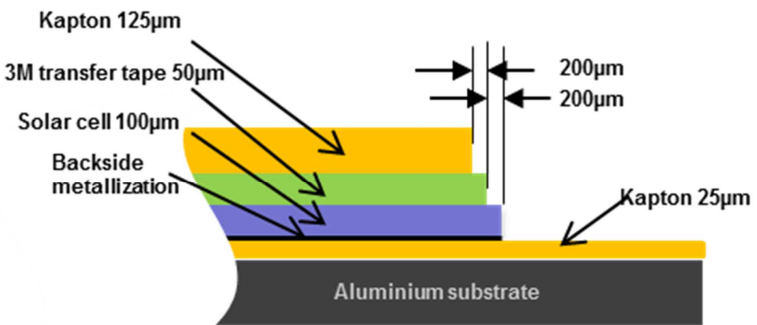

Fig. 14. Detail of cell edge. Cell configuration \#3

\section{2) Arcing test results}

In this configuration, no arc was detected up to SAS values of 500V-3A despite the fact that many tests were performed.

The explanation, to be confirmed by further tests with other sample types, could be that the adhesive transfer tape was too far from the backside metallization and did not cover the edge of the cell as it was supposed to be the case in configuration \#1 and then did not heat up enough to outgas.

\section{ARCING TESTS ON SOLAR CELL ALIKE SAMPLES}

\section{A. Solar cell alike - Config \#4}

\section{1) Sample description}

In this part, to understand the role of each material constituting a solar cell assembly, each material was replaced by an analog material in terms of electrical and thermal conductivity that is:

Backside metallization $\quad \rightarrow$ metallic plate (brass)

Silicon base coverglass glue $\rightarrow 3 \mathrm{M} \AA$ transfer tape

Coverglass

$\rightarrow 125 \mu \mathrm{m}$ Kapton ${ }^{\circledR}$ film

The first sample was made with $100 \mu \mathrm{m}$ brass plate covered with $125 \mu \mathrm{m}$ Kapton ${ }^{\circledR}$ film (Fig. 15 and Fig. 16). The Kapton film and the brass plate edges were aligned. The intercell gap was $0.5 \mathrm{~mm}$. 


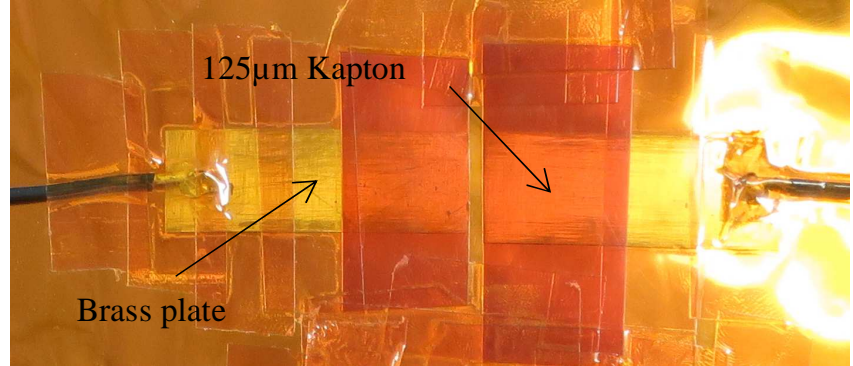

Fig. 15 : Cell alike configuration \#4

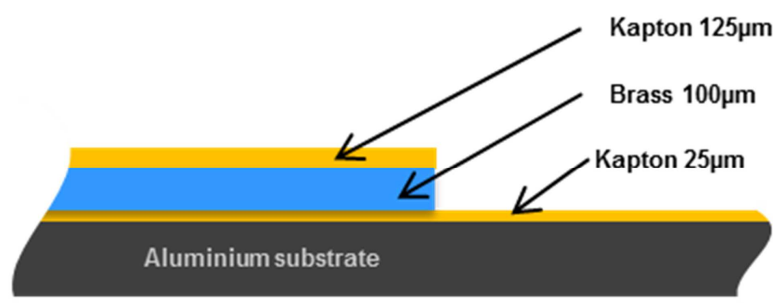

Fig. 16. Detail of cell edge. Cell configuration \#4

2) Arcing test results

In this configuration, no arc was detected up to SAS values of 350V-3A (maximum tested voltage).

\section{B. Solar cell alike- Config \#5}

\section{1) Sample description}

The second sample was made with $100 \mu \mathrm{m}$ brass plate covered with Kapton tape $\left(25 \mu \mathrm{m}\right.$ Kapton ${ }^{\circledR}+$ glue $)$. The Kapton tape and the brass plate edges were aligned (Fig. 17 and Fig. $18)$. The intercell gap was $0.5 \mathrm{~mm}$.

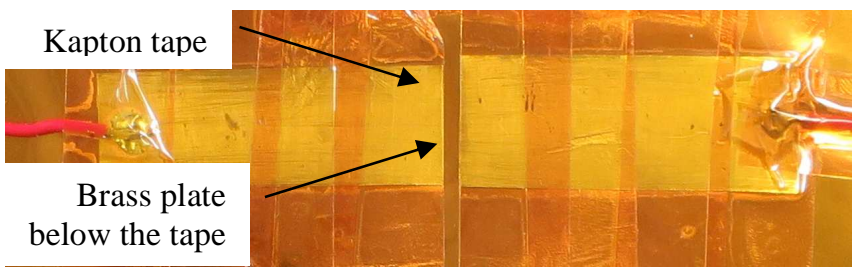

Fig. 17. Cell alike configuration \#5

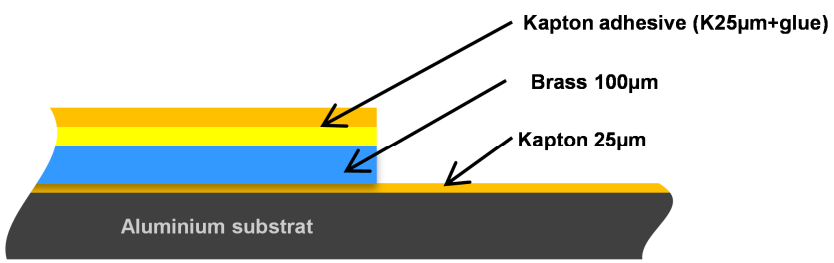

Fig. 18 : Detail of cell edge. Cell configuration \#5

\section{2) Arcing test results}

In this configuration, no arc was detected up to SAS values of 350V-3A (maximum tested voltage).

C. Solar cell alike- Config \#6

1) Sample description

The third sample was made with $100 \mu \mathrm{m}$ brass plate covered with $3 \mathrm{M} \circledast$ transfer tape and $125 \mu \mathrm{m}$ Kapton ${ }^{\circledR}$. The Kapton tape was slightly offset from brass plate edge. (Fig. 19 and Fig. 20). The intercell gap was $0.5 \mathrm{~mm}$.

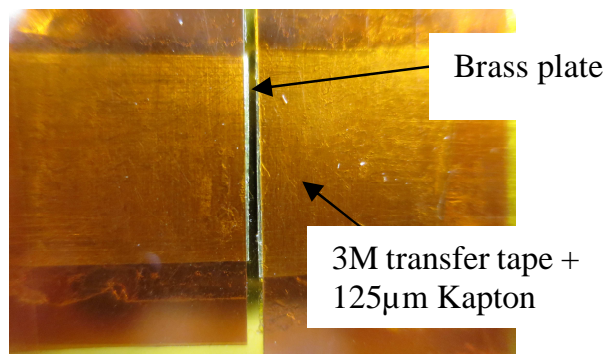

Fig. 19. Cell alike configuration \#6

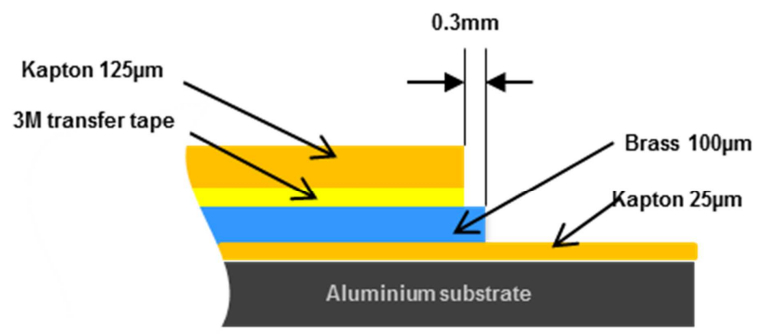

Fig. 20 : Detail of cell edge. Cell configuration \#6

\section{2) Arcing test results}

In this configuration, no arc was detected up to SAS values of 350V-3A (maximum tested voltage).

\section{Solar cell alike - Config \#7}

\section{1) Sample description}

At this point of the study, we thought that there was no arc because the metallic part collecting the plasma current was too thick and therefore did not heat up enough to create outgassing.

In this configuration the brass plate was then replaced by a thinner metallic plate picked up from an interconnector solar cell which was only $35 \mu \mathrm{m}$ thick (Fig. 21 and Fig. 22). The interconnector was covered with adhesive Kapton tape.

The intercell gap was $0.5 \mathrm{~mm}$.

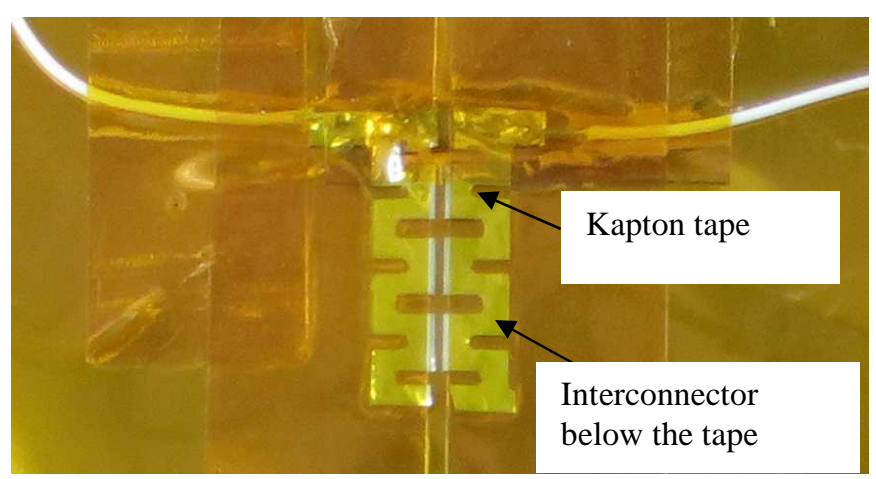

Fig. 21 Cell alike configuration \#7 


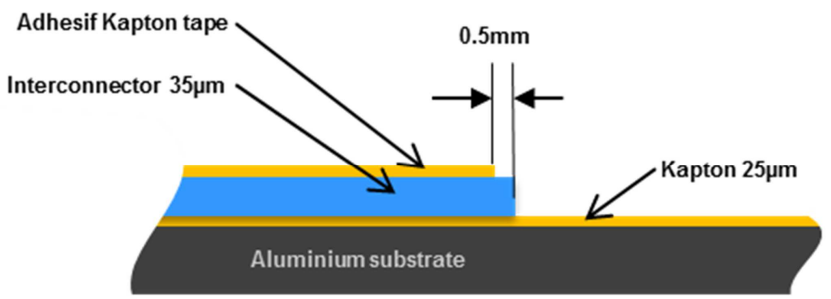

Fig. 22. Detail of cell edge. Cell configuration \#7

2) Arcing test results

In this configuration, no arc was detected up to SAS values of $350 \mathrm{~V}-3 \mathrm{~A}$, which is the maximum tested step.

\section{E. Solar cell alike - Config \#8}

\section{1) Sample description}

In this configuration Kapton tape glue (config \#7) was replaced by $3 \mathrm{M}$ transfer tape.

Different intercell gap from $0.5 \mathrm{~mm}$ to $2 \mathrm{~mm}$ were tested.

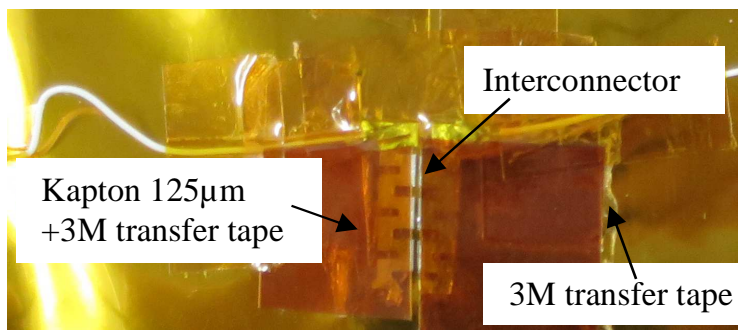

Fig. 23: Cell alike configuration \#8

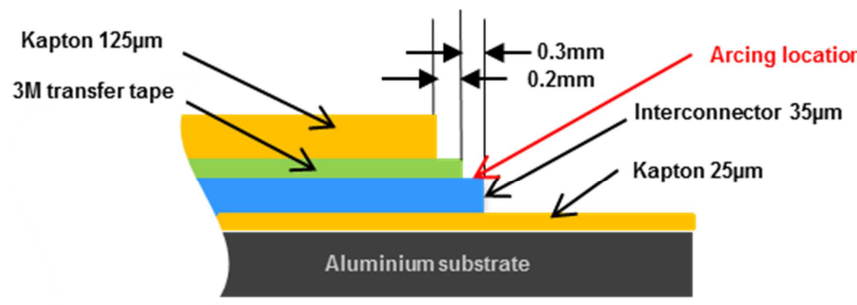

Fig. 24 : Detail of cell edge. Cell configuration \#8

2) Arcing test results

(1)

Gap $=0.5 \mathrm{~mm}$

Up to SAS value 200V-3A, no arc occurs. The first arc occurrence was for $300 \mathrm{~V}$ (arc current was still 3A). Arc duration was limited to $5 \mathrm{~ms}$. Arc voltage was about $50 \mathrm{~V}$. Anodic spot location was well determined on the interconnector by a bright-eroded area. The $3 \mathrm{M}$ transfer tape was not visible any more at the anodic spot location and melted around it (Fig. 25).

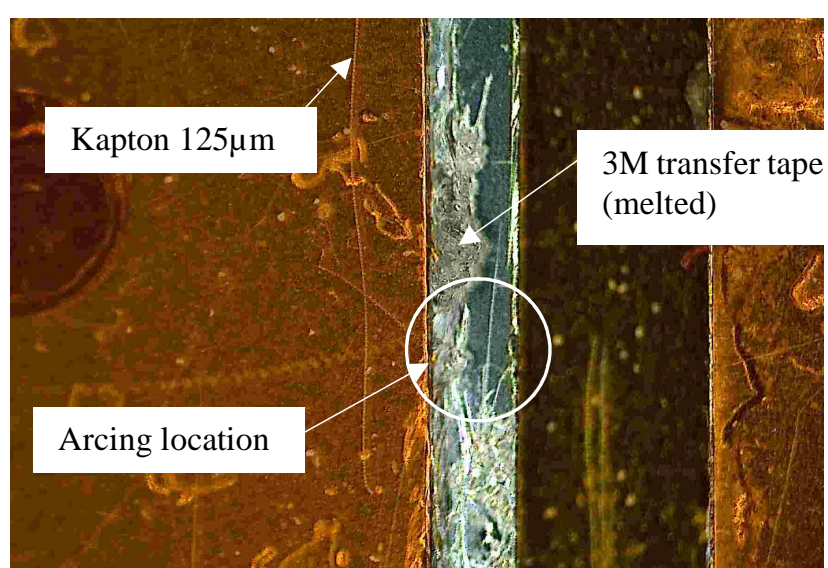

Fig. 25 : Arcing location in solar cell alike sample config \#8 $\mathrm{Gap}=0.8 \mathrm{~mm}$

Up to SAS value $280 \mathrm{~V}-3 \mathrm{~A}$, no arc occurred. The first arc occurrence was for SAS value $320 \mathrm{~V}-3 \mathrm{~A}$. Arc duration was $5 \mathrm{~ms}$ and arc voltage $30 \mathrm{~V}$.

\section{(3) $\quad$ Gap $=1 \mathrm{~mm}$ and $2 \mathrm{~mm}$}

Up to SAS value 500V-3A (maximum tested step), no arc occurred.

\section{CURRENT COLLECTION MEASUREMENT}

We have seen that the collected current was at the origin of secondary arc triggering. The current collecting surface for the solar cell sample is the edge of the rear side metallization. Therefore, it may present a funneling effect to collect enough current to heat the edge of the solar cell and thus the glue, knowing that for a sample made with an interconnector strip, the visible surface is about $2 \mathrm{~mm}^{2}\left(0.3 \times 7 \mathrm{~mm}^{2}\right)$.

We have measured the collected current versus SAS voltage for different sample types (see Fig. 26).

On this graph, the only configuration leading to an arc was the one represented by the points labeled "config8, gap $0.5 \mathrm{~mm}$ ". This result confirms that it is necessary to have a minimum collected current to trigger an arc. However, it is not the only required parameter since the collection can be high enough but the gap too large to trigger an arc (example of "config 8, gap $2 \mathrm{~mm}$ " where no arc was recorded).

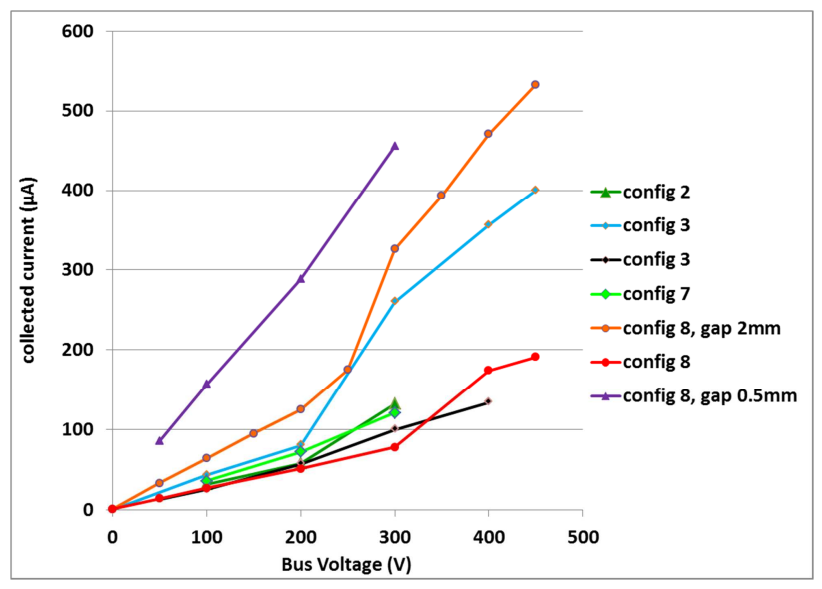

Fig. 26 : Example of collected plasma currents on different samples 


\section{ARCing TEST ON SOlAR CELls AT High Voltage}

In order to find the limit of arc occurrence for large gaps when the bus voltage is high (up to $600 \mathrm{~V}$ ), we have carried out a series of tests with $3 \mathrm{G} 30$ solar cells.

The first result was that, when the coverglass glue did not cover the edge of the solar cell (configuration schematized on Fig. 27), there was no arc for the following experimental conditions:

$$
\text { - } \quad \text { Gap }=0.8 \mathrm{~mm}
$$$$
\text { - } \quad \text { Vbus }=600 \mathrm{~V}
$$$$
\text { - Plasma density }=10^{12} \mathrm{~m}^{-3}
$$

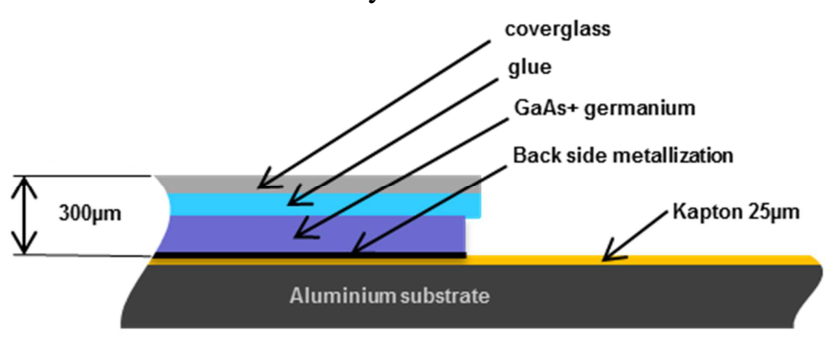

Fig. 27 : Cover glass glue not covering the solar cell edge

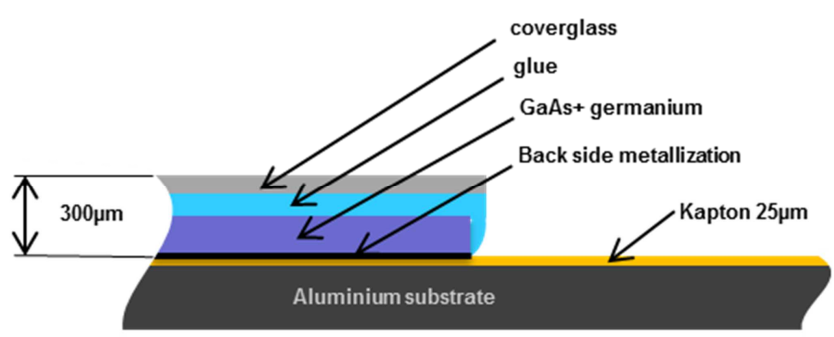

Fig. 28 : Cover glass glue covering the solar cell edge

Other tests were carried out on other 3G30 solar cells with coverglass glue covering the edge up to the backside metallization (Fig. 28).

The results are shown on TABLE 1 . As we can see, the arc-triggering threshold depends on solar cell gap and SAS voltage values, if the current is above the minimum required to maintain a secondary arc (3A). In this test, the arc duration was still limited to $6 \mathrm{~ms}$ not to damage sample.

TABLE 1 : ARCING RESULTS ON SOLAR CELL COUPONS WITH DIFFERENT GAPS AND VBUS VALUES

\begin{tabular}{|c|c|c|}
\hline $\mathrm{Gap}=0.5 \mathrm{~mm}$ & $\mathrm{SAS}=250 \mathrm{~V}-3 \mathrm{~A}$ & $\operatorname{arc}($ config \#1) \\
\hline $\begin{aligned} \text { Gap } & =0.8 \mathrm{~mm} \\
\text { Gap } & =1 \mathrm{~mm} \\
\text { Gap } & =1.2 \mathrm{~mm} \\
\text { Gap } & =1.5 \mathrm{~mm}\end{aligned}$ & $\mathrm{SAS}=600 \mathrm{~V}-3 \mathrm{~A}$ & arc \\
\hline \multirow{2}{*}{$\mathrm{Gap}=2 \mathrm{~mm}$} & $\mathrm{SAS}=600 \mathrm{~V}-3 \mathrm{~A}$ & no arc \\
\hline & $\mathrm{SAS}=700 \mathrm{~V}-3 \mathrm{~A}$ & arc \\
\hline \multirow{2}{*}{$\mathrm{Gap}=3 \mathrm{~mm}$} & $\mathrm{SAS}=600 \mathrm{~V}-3 \mathrm{~A}$ & no arc \\
\hline & $\mathrm{SAS}=700 \mathrm{~V}-3 \mathrm{~A}$ & arc \\
\hline Gap $=4 \mathrm{~mm}$ & \multirow{2}{*}{$\mathrm{SAS}=700-3 \mathrm{~A}$} & \multirow{2}{*}{ no arc } \\
\hline Gap $=6 \mathrm{~mm}$ & & \\
\hline
\end{tabular}

For SAS voltage $=700 \mathrm{~V}$ (maximum value available with our SAS), the maximum gap width which triggered an arc was $3 \mathrm{~mm}$.

\section{SUMMARY}

This study confirms previous results carried out in a R\&D CNES research program where it was observed that it was possible to trigger a secondary arc with plasma current collection on interconnectors or solar cell edges.

The secondary arc triggering mechanism is explained by the collection of plasma current (electrons) by interconnectors or solar cell edges which creates an increase of temperature at the current collection location. We estimated the power transferred to the collecting electrode (solar cell or other tested materials) by the collection of electrons. Their energy is $250 \mathrm{eV}$ when the electrode is biased to $250 \mathrm{~V}$, and the collected current necessary to induce an arc is about $400 \mu \mathrm{A}$ (see Fig. 26). The collecting surface is about $2 \mathrm{~mm}^{2}$, then the power is about $5.10^{4} \mathrm{~W} / \mathrm{m}^{2}$. A precise calculation should take into account heat conduction and dissipation, but a simple comparison of this power to solar radiation $\left(1350 \mathrm{~W} / \mathrm{m}^{2}\right.$ i.e. 40 times below) can help us to understand that temperature will increase significantly. This heating produces outgassing of the nearby coverglass glue, which increases the local pressure providing Paschen discharge conditions, making possible a secondary arc. Paschen minimum being about a few Torr.cm and the gap in the order of $\mathrm{mm}$, the pressure needs to be about 10 Torr i.e around 10-15 $\mathrm{hPa}$. This seems to be realistic to have such high pressure at gap's level.

Experimental tests were carried out to confirm this mechanism:

- The secondary arc triggering occurs on different solar cell types if there is coverglass glue.

- If there is no glue close to the collecting metallic strip or the solar cell edge, there is no arc.

- If a $125 \mu \mathrm{m}$ Kapton film replaces the coverglass and $3 \mathrm{M}$ transfer tape replaces coverglass glue, secondary arcs are also triggered.

- After a secondary arc occurrence, it was observed that it is difficult to trigger a second one. We assume that it is because the arc process has heated the glue (and even sometimes vaporized) and no more outgassing could occur.

- If the plasma current collecting electrode (interconnector) is too thick $(>35 \mu \mathrm{m})$, the overheating due to current collection is dissipated, the temperature does not increase up to outgassing levels, thus no arc occurs. Therefore, secondary arc may occur on any kind of structure where plasma electron current is collected by a thin metallic strip (interconnector or rear side solar cell metallization) and heats a material able to outgas.

- Secondary arcing thresholds are for:

- SAS values:

SAS current was fixed to $3 \mathrm{~A}$ in order to be sure that an arc could be sustained and SAS voltage was increased with $50 \mathrm{~V}$ steps up to $500 \mathrm{~V}$ or an arc triggering.

For a $0.5 \mathrm{~mm}$ gap the lower voltage level which triggered an arc was $250 \mathrm{~V}$.

\section{- Gap size:}

The same sample was tested with 4 gap values: - $0.5 \mathrm{~mm}$ : arc with SAS $=300 \mathrm{~V}-3 \mathrm{~A}$ 
- $0.8 \mathrm{~mm}:$ arc with SAS $=320 \mathrm{~V}-3 \mathrm{~A}$

- $1 \mathrm{~mm}$ : no arc up to SAS $=500 \mathrm{~V}-3 \mathrm{~A}$

- 2mm: no arc up to SAS $=500 \mathrm{~V}-3 \mathrm{~A}$

- Plasma density:

This parameter was not deeply studied. Only one test, performed on the same sample, gave the same arc threshold at 250V-3A for two plasma densities $5.10^{10} \mathrm{~m}-3$ and $7.10^{11} \mathrm{~m}^{-3}$.

The assumption that plasma density should affect the value of the collected current, therefore heating power, outgassing and thresholds was not verified.

Tests on solar cells with high values of Vbus and different gap sizes show that:

- To trigger an arc, the coverglass glue has to cover the cell edge up to the rear side of the cell,

- The wider the gap, the higher the voltage to trigger an arc,

- At Vbus $=700 \mathrm{~V}$ (maximum available value of our SAS), the gap width limit to trigger an arc is between 3 and $4 \mathrm{~mm}$.

\section{ACKNOWLEDGMENTS}

This work was performed in the frame of HV-EPSA Project funded by a "Horizon 2020" European research and innovation framework program.

The experiments were initiated in the frame of a R\&D CNES research program and the authors want to thank D. Payan, from CNES for his support.

\section{REFERENCES}

[1] T. A. Schneider et al., "Solar Arrays for Direct-Drive Electric Propulsion: Arcing at High Voltages," J. Spacecr. Rockets, vol. 42, no. 3, pp. 543-549, May 2005.

[2] S. Hess et al., "Semi-analytical model of the current collection by the interconnects and cell edges of high voltage solar panels exposed to LEO or thruster plume plasma: numerical models and comparison with experimental data," presented at the 14th SCTC, Kobe, Japan, 2018.

[3] G. A. Jongeward et al., "High Voltage Solar Arrays for a Direct-Drive Hall Effect Propulsion System," presented at the 27th International Electric Propulsion Conference, Pasadena, CA, 2001.

[4] Vayner B. and Galofaro J., "Ground tests of high-voltage solar array immersed in a low density plasma," presented at the 8th SCTC, Huntville (USA), 2003.

[5] I. G. Mikellides, G. A. Jongeward, T. Schneider, T. Peterson, T. W. Kerslake, and D. Snyder, "Solar arrays for direct-drive electric propulsion: Electron collection at high voltages," J. Spacecr. Rockets, vol. 42 , no. 3 , pp. 550-558, 2005.

[6] J. M. Siguier, V. Inguimbert, G. Murat, and D. Payan, "Secondary Arcing Triggered by Hypervelocity Impacts on Solar Panel Rear-Side Cables With Defects; Comparison With Laser Impacts," IEEE Trans. Plasma Sci., vol. 45, no. 8, pp. 1880-1886, Aug. 2017.

[7] H. Masui et al., "Electrostatic Discharge Tests of Solar Array Coupons With Different String-to-String Gaps Without RTV Adhesive Grout," IEEE Trans. Plasma Sci., vol. 40, no. 2, pp. 351-358, Feb. 2012.

[8] K. H. Wright, T. A. Schneider, J. A. Vaughn, B. Hoang, and F. K. Wong, "High-Current ESD Test of Advanced Triple Junction Solar Array Coupon," IEEE Trans. Plasma Sci., vol. 43, no. 9, pp. 29932999 , Sep. 2015.

[9] J.-M. Siguier, P. Sarrailh, J.-F. Roussel, V. Inguimbert, G. Murat, and J. SanMartin, "Drifting plasma collection by a positive biased tether wire in LEO-like plasma conditions: current measurement and plasma diagnostic," IEEE Trans. On Plasma Sci., vol. 41, no. 12, pp. 33803386, 2013.

[10] V. Inguimbert et al., "Electrostatic Discharge and Secondary Arcing on Solar Array; Flashover Effect on Arc Occurrence," IEEE Trans. Plasma Sci., vol. 36, no. 5, pp. 2404-2412, Oct. 2008.

[11] J. F. Roussel et al., "SPIS Open-Source Code: Methods, Capabilities, Achievements, and Prospects," IEEE Trans. Plasma Sci., vol. 36, no. 5, pp. 2360-2368, Oct. 2008. 